\title{
THE CONCEPT OF MANAGER: CRITICAL ANALYSIS AND COMPETENCIES REQUIRED
}

\author{
Tatjana N̦ikitina ${ }^{1}$, Inga Lapiņa ${ }^{2}$ \\ ${ }^{1,2}$ Faculty of Engineering Economics, Riga Technical University, Kalnciema 6, Rīga, Latvia \\ E-mails: ${ }^{1}$ tatjana.nikitina@rtu.lv (corresponding author); ${ }^{2}$ inga.lapina@rtu.lv
}

\begin{abstract}
The aim of the research is to analyse manager's competence groups, a manager role in modern enterprise and clarify what competences are required for managers in knowledge intensive business service (KIBS) organizations. Authors assumed that natural changes in the external environment lead to appearance and development of new managerial activities and competences or manifestation of a certain set of competencies. Previous researchers reveal that new context of teams that are diversified in terms of locations, disciplines and social groups require managers to act differently. Other researchers emphasize acceleration of technological novelties and presence of new organizational forms such as small and medium enterprises (SMEs) also creates new operational processes and managerial activities. Business society and labor market expect a professional who acts in different roles of entrepreneur, leader, and manager simultaneously. The authors conducted literature overview and identified ten leading competencies that are necessary for a manager in KIBS.
\end{abstract}

Keywords: manager, managerial competences, knowledge intensive business service (KIBS), business administration, management of technological innovation and R\&D, knowledge economy.

JEL Classification: M1, J24, O15, D83, M54, M12.

\section{Introduction}

Knowledge-based economy change landscape of the modern enterprises, non-profit organizations, educational institutions and government establishments. Affected by globalization, technology development, increasing role of ICT, and market demand workforce became more skilled than decades ago. Increasing role of information and knowledge guides to the growth in number of knowledge intensive business service (KIBS) organizations around the world, and, consequently in number of knowledge-rich jobs. It is important to equipped people with proper skills to secure their employability in knowledge society, and world leaders, such as International Labour Office (2011) or European Commission (2004) addressing the importance of the headline in their educational and labour development policies. Hereafter interest of scholars to the topic is up-to-date and respond to growing interest in the evolution of KIBS and more valuable skilled labour. OECD (2001) acknowledged new extra "workplace competencies' that are required for labour force in knowledge economy, and managerial occupations are the ones where changes in skills and abilities are expected even more than in others fields as the flat structured organizations, self-organized teams as virtual working groups and sustainability challenges are the actual context where managers have to evaluate risks and make operational and strategic decisions.

The aim of the research is to analyse manager's competence groups, a manager role in modern enterprise and clarifies what competences are required for managers in knowledge intensive business service (KIBS) organizations. The authors conducted literature overview to identify whether the ten leading competencies are necessary for a manager in KIBS.

\section{Literature review}

The authors analysed articles published by researchers who explored competencies for managers who operate in the field of knowledge economy and manage IT, banking and finance, insurance business, service management, and other KIBS organizations, see Table 1 below. 
Table 1. Overview of resources used for literature review (created by authors)

\begin{tabular}{|c|c|}
\hline Author & Essence of study \\
\hline Hong and Stahle (2003) & Competence-based Perspective on Knowledge Management \\
\hline European Commission (2004) & Report on innovation management and knowledge-based economy \\
\hline $\begin{array}{l}\text { Johnson, Lenartowicz, and Apud } \\
\text { (2006) }\end{array}$ & Cross-cultural competence in international business \\
\hline Mathews (2007) & Competences for IT C-level executives \\
\hline Ingasson and Jonasson (2009) & $\begin{array}{l}\text { International Project Management Association (IPMA) "Eye of Competence." } \\
\text { For project managers }\end{array}$ \\
\hline International Labour Office (2010) & G20 training strategy for workforce \\
\hline Maurer and Weiss (2009) & $\begin{array}{l}\text { Aspects of managerial work are associated with a need for competence at contin- } \\
\text { uous learning, aging workforce }\end{array}$ \\
\hline Chen and $\mathrm{Wu}(2011)$ & $\begin{array}{l}\text { IT management personnel and its impact on the performance as the C-level exec- } \\
\text { utives }\end{array}$ \\
\hline Denford and Chan (2011) & Manager's focus on knowledge capital in knowledge-based economy \\
\hline Gratton (2011) & Role of technology for managers \\
\hline $\begin{array}{l}\text { Wiek, Withycombe, and Redman } \\
\text { (2011) }\end{array}$ & Key competencies in sustainability \\
\hline Cikmačs (2012) & Competences for C-level executives in IT in Latvia \\
\hline Guðmundsson (2012) & Management in virtual teams \\
\hline Wang, Waldman, and Zhang (2012) & Leadership across cultures \\
\hline $\begin{array}{l}\text { Chipulu, Neoh, Ojiako, and Williams } \\
\text { (2013) }\end{array}$ & A Multidimensional Analysis of Project Manager Competences \\
\hline $\begin{array}{l}\text { Kuokkanen, Varje, and Väänänen } \\
\text { (2013) }\end{array}$ & Transformation of Finnish employees in post War period \\
\hline Caune et al. (2014) & Research on manager's capabilities in changing environment of SMEs in Latvia \\
\hline Nikic, Travica, and Mitrovic (2014) & Socio-emotional competences of managers \\
\hline $\begin{array}{l}\text { El-Sofany, H. M. Alwadani, and A. } \\
\text { Alwadani (2014) }\end{array}$ & Manager's competences in virtual teams \\
\hline Urosevic and Grahovic (2014) & Manager's competences required due to globalization and technological progress \\
\hline Barbato (2015) & Technological change and industry 4.0 impact on managers \\
\hline Boca and Radulescu (2015) & $\begin{array}{l}\text { A study about 'managers sophisticated in global management skills and working } \\
\text { with people from other countries' }\end{array}$ \\
\hline Carrillo (2015) & Changes due to transition from industrial to knowledge societies \\
\hline $\begin{array}{l}\text { Cichobłaziński, Pabian, Bylok, and } \\
\text { Zawada (2015) }\end{array}$ & Leadership skills in the turbulent environment \\
\hline $\begin{array}{l}\text { Lapina, Caune, Gaile-Sarkane, } \\
\text { Borkus, and Ozolinšs (2015) }\end{array}$ & Managers Competence Model in Dynamic Environment \\
\hline Verboncu and Condurache (2015) & Competencies for efficiency \\
\hline Zyl (2015) & ICT Project Manager Competence Model for financial service industry \\
\hline $\begin{array}{l}\text { Derwik, Hellström, and Karlsson } \\
(2016)\end{array}$ & Manager competences in logistics and supply chain \\
\hline $\begin{array}{l}\text { Osagie, Wesselink, Runhaar, and } \\
\text { Mulder (2016) }\end{array}$ & Corporate social responsibility impact on manager's skills \\
\hline Rosha and Lace (2016) & Coaching in the context of organizational change in Baltic states \\
\hline A. J. G. Silvius and G. Silvius (2016) & Sustainability competence for project managers \\
\hline Akhtar et al. (2017) & $\begin{array}{l}\text { Quantitative-focused techniques, big data analytics and data-driven applications } \\
\text { linked with the internet of things, relevant experience and analytical business ap- } \\
\text { plications as competences for top managers }\end{array}$ \\
\hline Delaney et al. (2017) & Case of a frontline manager skills development programme \\
\hline Nikitina and Lapina (2017) & Manager in cross-cultural teams \\
\hline Oosthuizen (2017) & Fourth Industrial Revolution Intelligence Framework for leaders \\
\hline Pauluzzo and Cagnina (2017) & intercultural competences in multinational contexts \\
\hline Sadovska and Kamola (2017) & Change management in banking and finance in 4IR \\
\hline Sarka and Ipsen (2017) & Information sharing via social media in software development companies \\
\hline Sedighi et al. (2017) & Electronic networks of practice $(\mathrm{ENoP})$ in organizations \\
\hline $\begin{array}{l}\text { Zieba, Bolisani, Paiola, and Scarso } \\
\text { (2017) }\end{array}$ & Insight into KIBS companies \\
\hline
\end{tabular}


For the purpose of the content analysis the authors reviewed academic, and periodicals sources as well as reports of official authorities, 40 items articles in total, where portion each of the source is distributed as $87 \%, 8 \%$, and $5 \%$ accordingly.

As per recommendations for qualitative content analysis developed by P. Mayring (2014), three segmentation rules or units of analysis have to be defined. The first one is the 'coding unit', or the smallest component of material within one category; in the study a specific word or phrase. The second one is the 'context unit', which defines the largest component in the category, a document page in the case. Finally, the third one, is the 'recording unit' that "determines which text portions are confronted with one system of categories", is an article or document, the complete list of the documents might be found in the Table 1 .

\section{Methodology of research}

The competences for managers are analysed applying Managers' competence groups developed by Lapina et al. (2015). The essence of the grouping is distribution of all managerial competencies into four groups as Professional, Personal and responsibility, leadership competencies, then Social and communication competencies, and Innovative and Learning competencies, see Table 2.

Hereafter the main question of the current research was followed: "Whether the competences that are identified by other researchers exploring managers' competencies in KIBS field resonates to the competencies that are defined above?'The following research hypothesis was developed by the authors: "Changes in external environment caused by knowledge-based industry have to lead to development of a new competencies set for manager".

Authors applied a technique of scientific literature content analysis to answer the main question of the research. To perform the analysis Nvivo for Mac version 11.4.3 (2084) was applied for coding while Nvivo 11 for Windows version 11.4.1064 (64 bit) was used for cluster analysis.

Text coding in the content analysis is considered as the first step, hence competences groups as four main nodes while competencies for each of the competence groups have been defined as sub-nodes, that are six sub-nodes for Professional competencies, ten for Personal competencies, another six for Social and communication competencies, and eight sub-nodes for Innovative and
Learning competencies (note the full list of Managers' Competence Groups in Methodology of research above).

Table 2. Manager's competence groups developed by Lapiņa et al. (2015)

\begin{tabular}{|c|c|}
\hline $\begin{array}{l}\text { Com- } \\
\text { pe- } \\
\text { tence } \\
\text { groups }\end{array}$ & Competencies \\
\hline 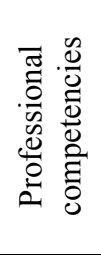 & $\begin{array}{l}\text { Ability to analyse and evaluate } \\
\text { Ability to plan } \\
\text { Ability to manage } \\
\text { Ability to motivate } \\
\text { Ability to react, delegate, and divide risks } \\
\text { Ability to present }\end{array}$ \\
\hline 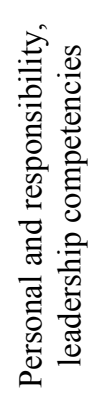 & $\begin{array}{l}\text { Leadership } \\
\text { Self-organisation and self-development } \\
\text { Responsibility } \\
\text { Collaboration } \\
\text { Erudition } \\
\text { Respect } \\
\text { Trustworthiness, loyalty } \\
\text { Intelligence } \\
\text { Intuition } \\
\text { Self-criticism (reasonable) }\end{array}$ \\
\hline 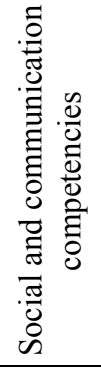 & $\begin{array}{l}\text { Ability to form relationships within the } \\
\text { company } \\
\text { Ability to form relationships outside the } \\
\text { company } \\
\text { Ability to persuade and motivate } \\
\text { Ability to form and organize teamwork } \\
\text { Ability to compromise, diplomacy } \\
\text { Ability to communicate in a foreign lan- } \\
\text { guage }\end{array}$ \\
\hline 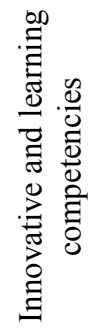 & $\begin{array}{l}\text { Ability to create (creativity) } \\
\text { Ability to spot and cease opportunities } \\
\text { Ability to generate ideas } \\
\text { Ability to take risk } \\
\text { Willingness to learn } \\
\text { Ability to promote employee development } \\
\text { Ability to pass on knowledge and skills } \\
\text { Ability to notice illogical issues }\end{array}$ \\
\hline
\end{tabular}

The next step is the content analysis and calculations of indicators. Jaccard's coefficient $(0=$ least similar, $1=$ most similar) was applied to identify a similarity between competences groups and the competencies itself. Visual representation of the cluster analysis demonstrates the nodes that have been coded similarly are clustered together on the diagram while the nodes that have been coded differently are displayed further apart. 


\section{Results and findings}

The authors identified strong relationship between competences groups where dominates correlation of Social and Personal competences groups, 0.94, as well as relationship between Professional and Innovative competence groups, 0.77 , that is proved by analysis result (see Table 3 ). The cluster analysis presented on Figure 1 demonstrates visual representation of the similarly mentioned above. The cluster analysis diagram of competencies for managers on the Figure 6 represents groups of competences more similar to each other than to others.

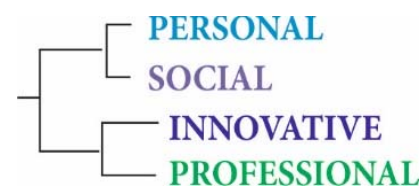

Figure 1. Cluster analysis results of the main nodes

Table 3. The relationship among competences groups (created by authors)

\begin{tabular}{|c|c|c|}
\hline Node A & Node B & $\begin{array}{l}\text { Jaccard's } \\
\text { coefficient }\end{array}$ \\
\hline $\begin{array}{l}\text { Nodes } \backslash \backslash \text { Idea } \\
\text { Lapina_Model } \backslash \backslash \\
\text { SOCIAL }\end{array}$ & $\begin{array}{l}\text { Nodes } \backslash \text { Idea } \\
\text { Lapina_Model } \backslash \\
\text { PERSONAL }\end{array}$ & 0.9429 \\
\hline $\begin{array}{l}\text { Nodes } \backslash \backslash \text { Idea_- } \\
\text { Lapina_Model } \backslash \backslash \\
\text { PROFESSIONAL }\end{array}$ & 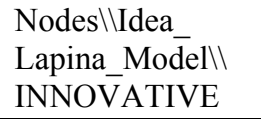 & 0.7714 \\
\hline $\begin{array}{l}\text { Nodes } \backslash \backslash \text { Idea } \\
\text { Lapina_Model } \backslash \backslash \\
\text { PERSONAL }\end{array}$ & $\begin{array}{l}\text { Nodes } \backslash \backslash \text { Idea } \\
\text { Lapina_Model } \backslash \\
\text { INNOVATIVE }\end{array}$ & 0.7368 \\
\hline $\begin{array}{l}\text { Nodes } \backslash \backslash \text { Idea } \\
\text { Lapina_Model } \backslash \\
\backslash \text { SOCIALL }\end{array}$ & $\begin{array}{l}\text { Nodes } \backslash \text { Idea } \\
\text { Lapina_Model } \backslash \\
\text { INNOVATIVE }\end{array}$ & 0.7368 \\
\hline $\begin{array}{l}\text { Nodes } \backslash \text { Idea } \\
\text { Lapina_Model } \backslash \backslash \\
\text { PROFESSIONAL }\end{array}$ & $\begin{array}{l}\text { Nodes } \backslash \backslash \text { Idea } \\
\text { Lapina_Model } \backslash \backslash \\
\text { PERSONAL }\end{array}$ & 0.7297 \\
\hline $\begin{array}{l}\text { Nodes } \backslash \backslash \text { Idea } \\
\text { Lapina_Model } \backslash \backslash \\
\text { SOCIAL }\end{array}$ & $\begin{array}{l}\text { Nodes } \backslash \backslash \text { Idea_- } \\
\text { Lapina_Model } \backslash \backslash \\
\text { PROFESSIONAL }\end{array}$ & 0.6842 \\
\hline
\end{tabular}

To continue with data exploration authors compared recognized frequency of coded subnodes within the researched sources to identify the most frequently mentioned and discussed competences. It was discovered that among Professional competencies for managers Ability to Analyse and Evaluate is the most repeated, see (Figure 2). It is important to mention that the competence is a leader not only in its own competence group, but also in the whole range of the competences reviewed in the context of the research).

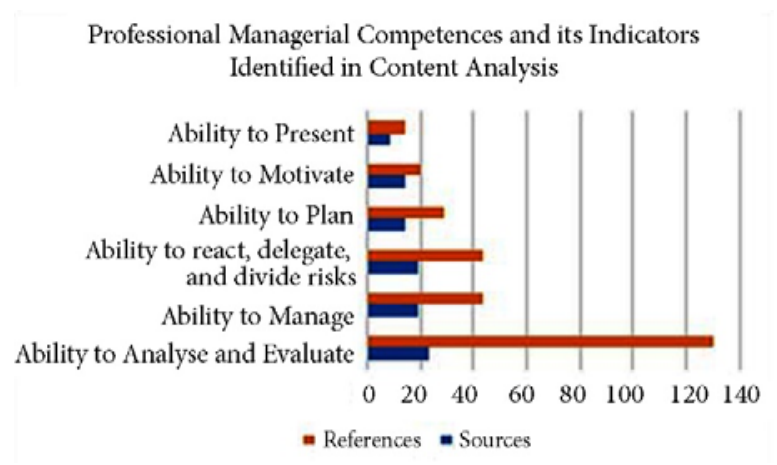

Figure 2. Professional managerial competencies and its indicators identified in content analysis (created by authors)

Reviewing Personal and responsibility, leadership competencies data authors observed that Leadership competence is dominated over rest in the group (see Figure 3).

Analysis of coded nodes for the third group of competences discovered that among Social and communication competences Ability to form relationship outside own organization is the most frequently discussed by others researchers (see Figure 4).

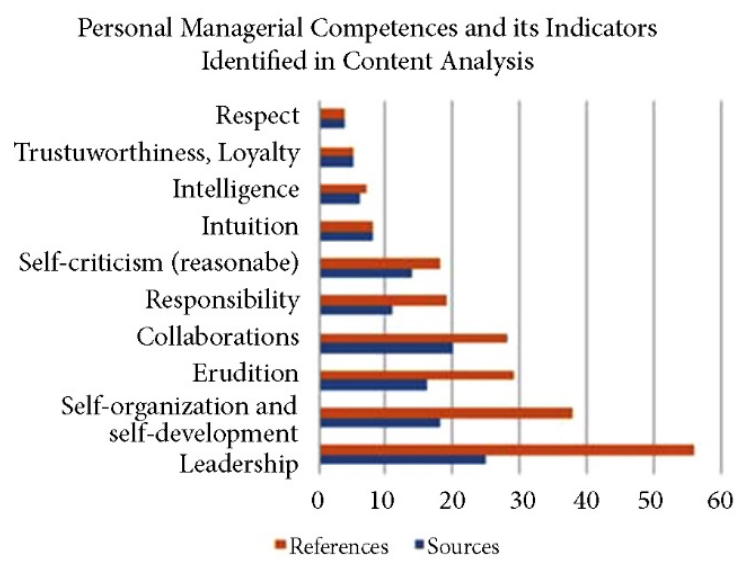

Figure 3. Personal competencies for managers and its indicators identified by content analysis (created by authors)

As per the fourth group of Innovative and learning competencies it was disclosed that the most intensively researched and described is a Willingness to learn competence (see Figure 5) that is the second most discussable competence after Ability to analyse and evaluate in the entire list of competencies. 
Social Managerial Competences and its Indicators Identified in Content Analysis

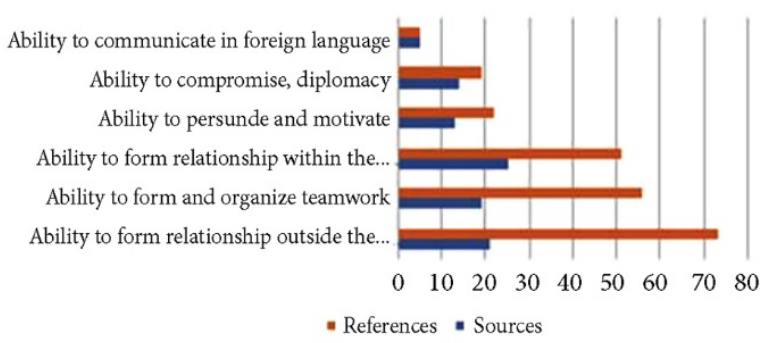

Figure 4. Social competencies for managers and its indicators identified in content analysis (created by authors)

The third step in the investigation was application of the techniques described in the first step of the analysis to identify relationship between competencies and construct cluster analysis diagram of the sub-nodes (see Table 4).

For the purposes of the research it was decided to inspect competencies where Jaccard's coefficient is the highest one that is varied from 0.65 to 0.50 (see example of the similarity analysis in Table 4) and discover how these competences are linked with the ones that have been identified as the most dominated in their own competence groups. The findings of the part is described in details in the forthcoming paragraphs.

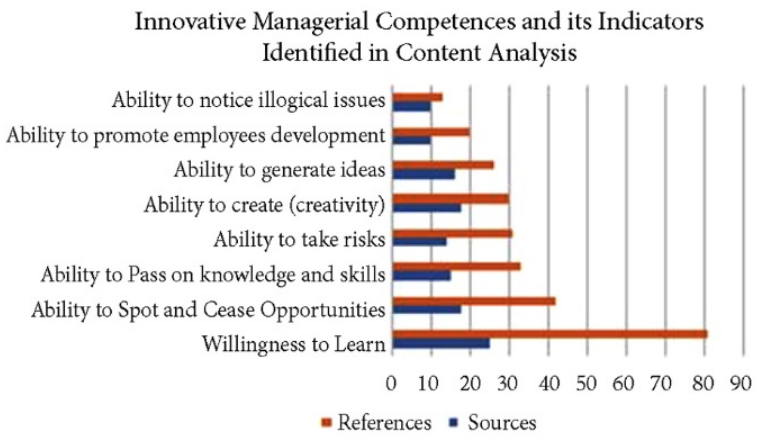

Figure 5. Innovative competencies for managers and its indicators identified in content analysis

Table 4. Relationship among managers'competencies

\begin{tabular}{|c|c|c|}
\hline Node A & Node B & $\begin{array}{c}\text { Jaccard's } \\
\text { coeffi- } \\
\text { cient }\end{array}$ \\
\hline $\begin{array}{l}\text { Nodes } \backslash \text { Idea } \\
\text { Lapina_Model } \backslash \backslash \\
\text { PERSONAL } \backslash \text { Collabor } \\
\text { ation }\end{array}$ & $\begin{array}{l}\text { Nodes } \backslash \backslash \text { Idea_- } \\
\text { Lapina_Model } \backslash \\
\text { INNOVATIVE } \backslash \\
\text { Ability to create } \\
\text { (creativity) }\end{array}$ & 0.6522 \\
\hline
\end{tabular}

End of Table 4

\begin{tabular}{|c|c|c|}
\hline Node A & Node B & $\begin{array}{c}\text { Jaccard's } \\
\text { coeffi- } \\
\text { cient }\end{array}$ \\
\hline $\begin{array}{l}\text { Nodes } \backslash \backslash \text { Idea } \\
\text { Lapina_ModeI } \backslash \backslash \\
\text { SOCIAL } \backslash A \text { bility to } \\
\text { form relationship out- } \\
\text { side the company }\end{array}$ & $\begin{array}{l}\text { Nodes } \backslash \backslash \text { Idea } \\
\text { Lapina_Model } \backslash \backslash \\
\text { SOCIAL } \backslash A \text { Ability } \\
\text { to form relation- } \\
\text { ship in company }\end{array}$ & 0.6429 \\
\hline $\begin{array}{l}\text { Nodes } \backslash \backslash \text { Idea } \\
\text { Lapina_Model } \backslash \backslash \\
\text { PERSONAL } \backslash \text { Collabor } \\
\text { ation }\end{array}$ & $\begin{array}{l}\text { Nodes } \backslash \backslash \text { Idea } \\
\text { Lapina_Model } \backslash \backslash \\
\text { SOCIAL } \backslash \text { Ability } \\
\text { to form relation- } \\
\text { ship outside the } \\
\text { company }\end{array}$ & 0.6400 \\
\hline $\begin{array}{l}\text { Nodes \\
Idea } \\
\text { Lapina_Model } \backslash \backslash \\
\text { PERSONAL } \backslash \text { Erudition }\end{array}$ & $\begin{array}{l}\text { Nodes } \backslash \backslash \text { Idea } \\
\text { Lapina_Model } \backslash \backslash \\
\text { PERSONAL } \backslash \text { Coll } \\
\text { aboration }\end{array}$ & 0.6364 \\
\hline $\begin{array}{l}\text { Nodes } \backslash \backslash \text { Idea } \\
\text { Lapina_Model } \backslash \backslash \\
\text { SOCIAL } \backslash A \text { Ability to } \\
\text { form relationship out- } \\
\text { side the company }\end{array}$ & $\begin{array}{l}\text { Nodes } \backslash \backslash \text { Idea } \\
\text { Lapina_Model } \backslash \backslash \\
\text { INNOVATIVE } \backslash \\
\text { Ability to create } \\
\text { (creativity) }\end{array}$ & 0.6250 \\
\hline $\begin{array}{l}\text { Nodes \\
dea-} \\
\text { Lapina_Model } \backslash \backslash \\
\text { INNOVATIVE\Abilit } \\
\text { y to spot and cease op- } \\
\text { portunities }\end{array}$ & 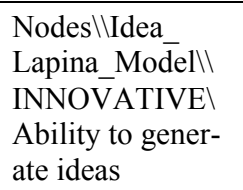 & 0.6190 \\
\hline $\begin{array}{l}\text { Nodes } \backslash \backslash \text { Idea } \\
\text { Lapina_Model } \backslash \backslash \\
\text { PROFESSIONAL } \backslash A b i \\
\text { lity to react, delegate, } \\
\text { and divide risks }\end{array}$ & $\begin{array}{l}\text { Nodes } \backslash \text { Idea } \\
\text { Lapina_Model } \backslash \backslash \\
\text { PROFESSIONA } \\
\text { L\Ability to Ana- } \\
\text { lyse and Evaluate }\end{array}$ & 0.6154 \\
\hline $\begin{array}{l}\text { Nodes } \backslash \backslash \text { Idea_- } \\
\text { Lapina_Model } \backslash \backslash \\
\text { PERSONAL } \backslash \text { Leadersh } \\
\text { ip }\end{array}$ & $\begin{array}{l}\text { Nodes } \backslash \backslash \text { Idea } \\
\text { Lapina } M \text { Model } \backslash \backslash \\
\text { SOCIAL } \backslash \text { Ability } \\
\text { to form relation- } \\
\text { ship in company }\end{array}$ & 0.6129 \\
\hline $\begin{array}{l}\text { Nodes } \backslash \backslash \text { Idea } \\
\text { Lapina_Model } \backslash \backslash \\
\text { PERSONAL } \backslash \text { Erudition }\end{array}$ & $\begin{array}{l}\text { Nodes } \backslash \backslash \text { Idea } \\
\text { Lapina_Model } \backslash \backslash \\
\text { SOCIAL } \backslash A \text { bility } \\
\text { to form relation- } \\
\text { ship outside the } \\
\text { company }\end{array}$ & 0.6087 \\
\hline $\begin{array}{l}\text { Nodes } \backslash \backslash \text { Idea } \\
\text { Lapina_Model } \backslash \backslash \\
\text { PERSONAL\Collabor } \\
\text { ation }\end{array}$ & $\begin{array}{l}\text { Nodes } \backslash \backslash \text { Idea } \\
\text { Lapina_Model } \backslash \backslash \\
\text { SOCIAL } \backslash A b i l i t y \\
\text { to form relation- } \\
\text { ship in company }\end{array}$ & 0.6071 \\
\hline $\begin{array}{l}\text { Nodes } \backslash \backslash \text { Idea } \\
\text { Lapina_Model } \backslash \backslash \\
\text { INNOVATIVE } \backslash \text { Willin } \\
\text { gness to learn }\end{array}$ & $\begin{array}{l}\text { Nodes } \backslash \backslash \text { Idea } \\
\text { Lapina_Model } \backslash \backslash \\
\text { PERSONAL } \backslash \text { Coll } \\
\text { aboration }\end{array}$ & 0.6071 \\
\hline
\end{tabular}

It was observed that Ability to analyse and evaluate has well-built correlation to the competencies in all four competence groups as follows: a) Ability to react, delegate, and divide risks (Professional group), 0.62 , b) Ability to form relation- 
ship in the organization, 0.6 and outside the organization, 0.57 (both from Social group), c) Collaboration competence (Personal group), 0.59, and d) Ability to create (creativity) (Innovative group), 0.58 . Interestingly to note that the least similarity the Ability to analyse and evaluate demonstrated to Intuition competence, 0.24 , from Personal group. It was obvious to the authors to observe that inside its own competence group, Ability to analyse and evaluate holds relationship with Ability to delegate, 0.62 , and Ability to plan, 0.62; however Ability to motivate and Ability to present hold feeble relations with the main competence, 0.22 in both cases. As per authors, the finding might be explained with increasing role of collaboration and new forms of relationships among team members in self-organized teams and flat structured organizations that form KIBS enterprises' landscape (Denford and Chan, 2011; Gu, 2012; El-Sofany et al., 2014; Sedighi et al., 2017).

Not a surprise that Leadership competence from Personal and responsibility group was addressed by other researchers more often than others debating about competences for managers, that is why it is important to note that the most strongest relationship was observed between Leadership and Ability to form relationship inside the organization, 0.61 , and the Ability to organize a teamwork (both from Social group), 0.57. Unexpectedly to the authors, Ability to communicate in foreign languages (Social group), Ability to promote employee development, and Ability to pass on knowledge and skills (both from Innovative group) demonstrated very weak relationship to Leadership skills, that are $0.15,0.21$, and 0.21 accordingly. It is worth mentioning that inside the Personal group the following competencies besides the Leadership, demonstrates strong link between each other: a) Erudition and Collaboration, 0.64, b) Self-organization and Self-development with Collaboration, 0.58 , and c) Self-organization and Self-development and Self-organization with Erudition, 0.55. Later in the article we will discuss that the competences also has a strong correlation with Willingness to learn, that is a part of Innovative group, hence it might be interpreted as demand for personal competences oriented towards a new knowledge acquiring and creation, that seems as quite logical for KIBS organizations.

As was mentioned above, a central competence for discussions in Social group is a manager's Ability to for relationship outside the company, hence the authors were not astonished when recognized that the strongest relationship the competence has with the competence that is very close by all skills and expertise - to another competence from Social group, Ability to form relationship inside the company, 0.64 . Interestingly that it also has relationship with ability to create or creativity (Innovative group), 0.63 , and Ability to Analyse and Evaluate (Professional group), 0.57, that might be explained by the Open Innovation theory and other researchers that emphasize importance of reciprocal knowledge exchange between external stakeholders for a purpose to create a new product (European Commission, 2012; Bettiol et al., 2015; Sarka \& Ipsen, 2017; Zieba et al., 2017). The authors discovered that the competence is characterized by unexpectedly weak relationship to a seemingly vital competence, such Social group's competence as Ability to communicate in foreign languages, 0.23 . Ability to compromise and diplomacy (Social group) also has a relatively low relationship with the main competence, 0.40 .

Finally, analysing interdependencies between Willingness to learn, an essential for researchers' discourse in Innovative and learning competencies group, authors realized that the most tight relationships the competence posses with the following set: a) Collaboration, 0.61, b) Self-organization and self-development (both from Personal group), 0.59 , c) Ability to from relationship outside and inside the company (Social group), 0.59 and 0.56, and d) Erudition (Personal group), 0.58 .

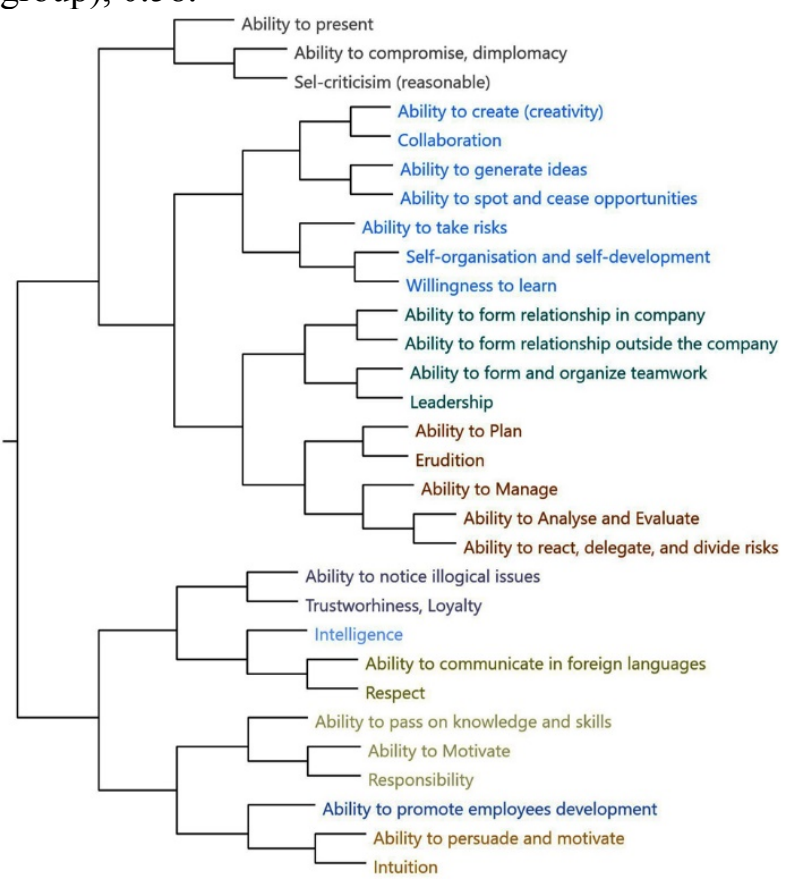

Figure 6. Cluster analysis diagram of competencies for managers 
The authors also found that internally its own Innovative and learning competencies group, Willingness to learn has a relationship with Creativity, 0.54, and Ability to spot and cease opportunities, 0.54 . The findings is vital, as lead authors to a conclusion that innovative and learning abilities for managers in KIBS organizations are not based only on an individual's curiosity but also is a result of self-discipline and collaboration with external and internal stakeholders. Authors' attention also was caught by the observation of weak relationships between Willingness to learn and Personal Intelligence, 0.19, Ability to communicate in foreign languages (Social group), 0.20 , and Intuition (Personal group), 0.22. As the similar findings have been done earlier by the authors in the context of explorations the competencies from Professional group, then it lead them to a conclusion that due to globalization and multiculturalization of modern KIBS organizations, Ability to speak in foreign languages is considered as natural, and hereafter is not assumed as curious for research and discussion. Similarly, the importance of Intuition competence is blurred as a result of management decision making based on system thinking, facilitated IT and computing technologies, and big data.

Content analysis demonstrated that there are two groups of competencies for managers that are most related to each other. This is a pair of Personal and responsibility, leadership competencies and a group of Social and communication competencies (see Figure 7).

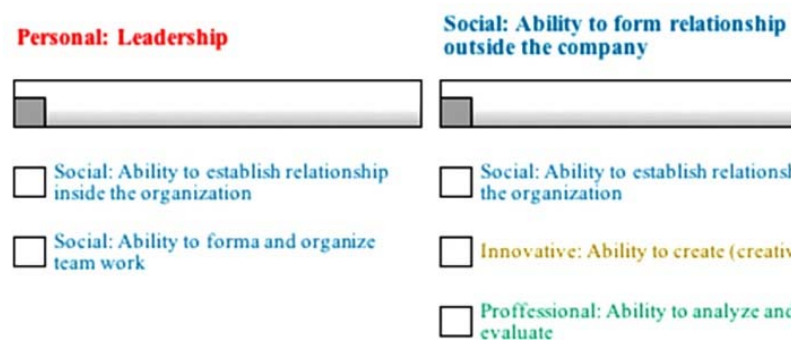

Figure 7. Relation of Personal and Social competence groups for managers

Another pair is a set of Professional competencies and a group of Innovative and learning competencies (see Figure 8).

Consequently, the authors analysed the concept of Managers' competence groups and role of the Professional, Personal, Social and Communication, as well as Innovative and Learning competencies in modern KIBS enterprise and clarified significance of the competencies for a manager in the environment.

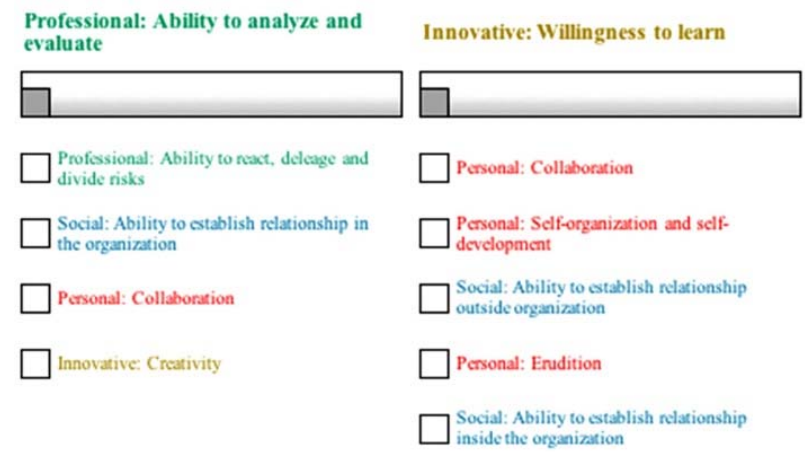

Figure 8. Relations of Professional and Innovative competence groups

\section{Conclusions}

The authors have analysed 34 articles of different researchers to identify how Manager's competence groups developed by Lapina et al. (2015) will resonate in the field of manager's competence to operate in KIBS organizations. It was discovered that

- researchers tend to pair Personal and Social groups of competences and separately the Professional and Innovative groups;

- In the Social and Communication group the Ability to form relationship inside the organization has strong linkage to key competence in each of the competence groups, that are Leadership, Ability to build relationship outside the organization, Ability to analyse and evaluate, and Willingness to learn;

- In the Professional group the Ability to analyse and evaluate is the most researched and frequently discussed by other researchers, and has stable correlation to each of the competence groups;

- Willingness to learn is the key competence from Innovative and Learning group possess a sustainable linkage to Personal and Social competence group;

- The competences that have strong connections with key competences in each group are overlapping between the groups.

Hereafter, the authors made a conclusion that the key competences and the ones that have strongest relations with them shape a set of a manager's competences in KIBS organization that might be listed as follows:

1. Ability to analyse and evaluate;

2. Ability to react, delegate, and divide risks; 
3. Ability to form relationship inside and outside of organization;

4. Collaboration;

5. Ability to create (creativity);

6. Willingness to learn;

7. Self-organization and self-development;

8. Erudition;

9. Teamwork;

10. Leadership.

To continue discussion on the implications of the findings and as recommendations for future investigations and other researchers, the authors suggest to analyse variance in performance of KIBS organizations where managers' competences are represented in accordance to the new findings listed above. Another perspective direction of the research is to identify how the findings resonate in different countries depends on index of knowledge economy and maturity in the field. Finally, it is worth exploring narrowed segments of the KIBS organizations to recognize what competences are demanded by specified industries as well as regions.

\section{References}

Akhtar, P., Khan, Z., Frynas, J. G., Tse, Y. K., \& Rao-Nicholson, R. (2017). Essential micro-foundations for contemporary business operations: top management tangible competencies, relationship-based business networks and environmental sustainability. British Journal of Management, 29(1), 43-62. https://doi.org/10.1111/1467-8551.12233

Barbato, M. (2015). Inside Amberg: Industry 4.0 In Action. 4 November 2015. Retrieved from https://www.managers.org.uk/insights/news/2015/november/inside-amberg-industry-4-in-action

Bettiol, M., Marchi, V. D., \& Maria, E. D. (2015). Developing capabilities in new ventures: a knowledge management approach. Knowledge Management Research \& Practice, (2015), 1-9.

Boca, G. D., Radulescu, C., Toader, R., \& Toader, C., (2015). A cross cultural model for flexiblemotivation in management. Annals of "Dunarea de Jos" University of Galati Fascicle I. Economics and Applied Informatics. Years XXI - no1/2015. ISSN-L 1584-0409.

Carrillo, F. J. (2015). Knowledge-based development as a new economic culture. Journal of Open Innovation: Technology, Market, and Complexity, 1(1), 15. https://doi.org/10.1186/s40852-015-0017-5

Chen, Y. C., \& Wu, J. H. (2011). IT management capability and its impact on the performance of a CIO. Information and Management, 48(4-5), 145-156. https://doi.org/10.1016/j.im.2011.04.001

Chipulu, M., Neoh, J. G., Ojiako, U., \& Williams, T. (2013). A multidimensional analysis of project manager competences. IEEE Transactions on Engineering Management, 60(3), 506-517.

https://doi.org/10.1109/TEM.2012.2215330

Cikmačs, K. (2012). What competencies should CIO have in companies in Latvia ? Riga SSE, 2012 (Vol. 4).
Cichobłaziński, L., Pabian, A., Bylok, F., \& Zawada, M. (2015). Ethical leadership based on organizational conflict management in collective disputes resolution. Proceedings of the European Conference on Management, Leadership \& Governance (pp. 81-88).

Delaney, Y., Pattinson, B., McCarthy, J., \& Beecham, S. (2017). Transitioning from traditional to problembased learning in management education: the case of a frontline manager skills development programme. Innovations in Education and Teaching International, 54(3), 214-222.

https://doi.org/10.1080/14703297.2015.1077156

Denford, J. S., \& Chan, Y. E. (2011). Knowledge strategy typologies: defining dimensions and relationships. Knowledge Management Research and Practice, 9(2), 102-119. https://doi.org/10.1057/kmrp.2011.7

Derwik, P., Hellström, D., \& Karlsson, S. (2016). Manager competences in logistics and supply chain practice. Journal of Business Research, 69(11), 4820-4825. https://doi.org/10.1016/j.jbusres.2016.04.037

El-Sofany, H. F., Alwadani, H. M., \& Alwadani, A. (2014). Managing virtual team work in IT projects: survey. International Journal of Advanced Corporate Learning (iJAC), 7(4), 28. https://doi.org/10.3991/ijac.v7i4.4018

European Commission. (2012). Knowledge-intensive (business) services in Europe. https://doi.org/10.2777/59168

European Commission. (2004). Innovation management and the knowledge driven economy. Retrieved from https://publications.europa.eu/en/publication-detail//publication/dd46213f-89e1-4c20-ad21-f3adca0b0f7f

Gratton, L. (2011). Middle manager muddle. Harvard Business Review, (Jan-February), 36.

Guðmundsson, A.H. (2012). What are the success factors for project leaders in virtual teams? Reykjavik University / MPM-program / Final Project MPM2012. (C) 2012, MPM-Program, Reykjavik University, Menntavegi 1, 101 Reykjavik.

Hong, J. \& Stahle, P. (2003, August). Competence-based perspective on knowledge management and its strategic implications. Paper submitted for The 17th Nordic Conference on Business Studies. Reykjavik.

International Labour Office. (2011). A skilled workforce for strong, sustainable and balanced growth: a G20 training strategy. Education And Training.

Johnson, J. P., Lenartowicz, T., \& Apud, S. (2006). Crosscultural competence in international business: toward a definition and a model. Journal of International Business Studies, 37(4), 525-543. https://doi.org/10.1057/palgrave.jibs. 8400205

Kuokkanen, A., Varje, P., \& Väänänen, A. (2013). Transformation of the Finnish employee ideal in job advertisements from 1944 to 2009. Acta Sociologica (United Kingdom), 56(3), 213-226. https://doi.org/10.1177/0001699313477871

Lapiņa, I., Caune, J., Gaile-Sarkane, E., Borkus, I., \& Ozolinšs, M. (2015, July). Development of managers competence model in dynamic environment. Proceedings of the 19th World Multi - Conference on Systemics, Cybernetics and Informatics, 2 (Wmsci) (pp. 219224). United States of America, Orlando.

Maurer, T. J., Weiss, E. M., Maurer, T. J., \& Weiss, E. M. (2017). Continuous learning skill demands: associations with managerial job content, age, and experience. Journal of Business and Psychology, 25(1), 1-13. https://doi.org/10.1007/s10869-009-9126-0 
Mayring, P. (2014). Qualitative content analysis: theoretical foundation, basic procedures and software solution. Klagenfurt, 2014. Retrieved from http://nbn-resolving.de/urn:nbn:de:0168-ssoar-395173

Muller, E., \& Doloreux, D. (2007). The key dimensions of knowledge- intensive business services (KIBS) analysis: a decade of evolution. Working Papers Firms and Region No. U1/2007.

Mathews, C. (2007). The secrets of C-suite success. CIO, 20(18), 57-64.

Nikic, G., Travica, V., \& Mitrovic, M. (2014). Differences between employees and managers regarding socioemotional competences. Serbian Journal of Management, 9(2), 281-292. https://doi.org/10.5937/sjm9-5440

Nikitina, T. \& Lapina, I. (2017, May). Manager's competence to lead cross-cultural teams. RTU International Scientiic Conference Economics and Management ICEM 2017 (pp. 47-48). Riga, Latvia.

OECD. (2001). Report on competencies for knowledge economy. Retrieved from http://www.oecd.org/innovation/research/1842070.pdf

Oosthuizen, J. H. (2017). The determinants of fourth industrial revolution leadership dexterity: a proposed framework for 4IR-intelligence and subsequent 4IR leadership development. 4th International Conference on Responsible Leadership, (March).

Osagie, E. R., Wesselink, R., Runhaar, P., \& Mulder, M. (2017). Unraveling the competence development of corporate social responsibility leaders: the importance of peer learning, learning goal orientation, and learning climate. Journal of Business Ethics, 1-16. https://doi.org/10.1007/s10551-017-3638-8

Pauluzzo, R., \& Cagnina, M. R. (2017). Bridging the divide: intercultural competences to reconcile the knowledge transfer dilemma in multinational contexts. Knowledge Management Research and Practice, 15(4), 542-550. https://doi.org/10.1057/s41275-017-0073-7

Rosha, A., \& Lace, N. (2016). The scope of coaching in the context of organizational change. Journal of Open Innovation: Technology, Market, and Complexity, 2(1), 2. https://doi.org/10.1186/s40852-016-0028-x
Sadovska, K. \& Kamola, L. (2017, May). Change management in operations in banking sector during $4^{\text {th }}$ industrial revolution. RTU International Scientiic Conference Economics and Management ICEM 2017 (pp. 4346). Riga, Latvia.

Sarka, P., \& Ipsen, C. (2017). Knowledge sharing via social media in software development: a systematic literature review. Knowledge Management Research \& Practice, 15(4). https://doi.org/10.1057/s41275-017-0075-5

Sedighi, M., Lukosch, S., Van Splunter, S., Brazier, F. M. T., Hamedi, M., \& Van Beers, C. (2017). Employees' participation in electronic networks of practice within a corporate group: Perceived benefits and costs. Knowledge Management Research and Practice, 15(3), 460-470 https://doi.org/10.1057/s41275-017-0059-5

Silvius, A. J. G., \& Silvius, G. (2016). Sustainability as a competence of project managers. PM World Journal, $V($ IX), 1-13. Retrieved from www.pmworldlibrary.net

Verboncu, I., \& Condurache, A. (2015). About managers, competence and efficiency. Review of International Comparative Management, 16(3), 314-324.

Wang, H., Waldman, D. A., \& Zhang, H. (2012). Strategic leadership across cultures: current findings and future research directions. Journal of World Business, 47(4), 571-580. https://doi.org/10.1016/j.jwb.2012.01.010

Wiek, A., Withycombe, L., \& Redman, C. L. (2011). Key competencies in sustainability: a reference framework for academic program development. Sustainability Science, 6(2), 203-218. https://doi.org/10.1007/s11625-011-0132-6

Zieba, M., Bolisani, E., Paiola, M., \& Scarso, E. (2017). Searching for innovation knowledge: Insight into KIBS companies. Knowledge Management Research and Practice, 15(2), 282-293. https://doi.org/10.1057/s41275-017-0050-1

Zyl, D. (2015). An evolutionary ICT project manager competence model for the South African financial services industry. PM World Journal, 4(12), 1-21. 